\title{
The Effect of the Learning Approaches and the Vocabulary Mastery on the French Learning Outcomes
}

\author{
Siti Annisa Lubis \\ Departement of Educational Technology \\ Postgraduate Program \\ Medan, Indonesia \\ Email : razorx44erz@gmail.com
}

\author{
Julaga Situmorang, R. Mursid \\ Departement of Educational Technology \\ Postgraduate Program \\ Medan, Indonesia
}

\begin{abstract}
The aim of this research is for knowing the effect of learning approaches and vocabulary mastery towards French learning outcomes. The learning approaches used in this research are Perspective Actionnelle and Communicative Approach. The research method was quasi-experimental study using factorial $2 \mathrm{x}$ 2 designs. The population consisted of 800 students in the second grade of senior high school in SMA Negeri 3 Medan in the first semester 2018-2019 academic year and the sample consisted of 80 students. The technique of data analysis used is ANOVA two ways. The conclusion of the research shows that (1) there is difference between students French learning outcomes which is taught using Perspective Actionnelle with Communicative Approach. The learning outcomes of French taught by using Perspective Actionnelle is higher than the learning outcomes of French taught by using Communicative Approach, (2) there is a difference between students French learning outcomes who have higher vocabulary mastery and the lower ones. (3) there is significance interaction between the utilization of learning method and the vocabulary mastery on learning outcomes.
\end{abstract}

Keywords: Learning Approaches, Perspective Actionnelle, Communicative Approach, Vocabulary mastery

\section{INTRODUCTION}

Nowadays, mastering various foreign languages in communicating is increasingly important. Foreign language skills can then be used to facilitate understanding in obtaining information from several countries. In the end, the information obtained can be used to develop knowledge in various fields such as tourism, hospitality, education, fashion, interior design, architecture, mechanical engineering, aviation engineering (aeronautics), and etc.

According to Leclerc, "French is the 11th most spoken language in the world. Until 1999, this language was spoken by more than 77 million people in the world as a mother tongue and by 128 million other people as a second language". French is also one of the six official languages used by the United Nations. In addition, mastery of French is needed to continue studies at the tertiary level in France. Because, based on [3], "France is one of the countries that many students aim to continue with high quality education with the most affordable tuition fees in the world". French is also needed for students who want to continue their studies in other countries that use the language as a national language, such as Canada, Switzerland, Belgium, Monaco, Luxembourg, and so on.
French subjects are one of the specialization subjects taught in senior high school. Many approaches can be used in language learning, so the teacher must be able to master various concepts related to students' language development. Skills in teaching are needed so that students can master four aspects of language skills, namely listening skills (la comprehension orale), speaking (la production orale), reading (la comprehension écrite), and writing (la production écrite). These four skills are important to learn so that language's users can communicate well.

In Indonesia, French is taught in several high schools, vocational schools, and also universities. The French language teaching and learning program in Indonesia should also lead to the development of students / students in the face of current globalization, so that the learning process must be well planned. The teaching role in the learning process is very important. Therefore, a teacher must have some knowledge and ability to choose and apply various effective and efficient teaching methods in the classroom. Based on its development, methods or approaches in foreign language learning have experienced some progress. In Medan, one of the high schools that teach French is in the Public Senior High School (SMA Negeri 3 Medan). Based on observations at the school, there were still many students who scored below the Minimum Passing Grade (MPG). Although the teacher has made various efforts to improve student learning outcomes, but the value of students in French is still low. After conducting interviews and observations with teachers at the school, the teacher used a communicative approach in training students' ability to speak, and a deductive approach to teaching grammar. In addition, as a learning medium, teachers have used various media in learning, such as power point, video, and etc. Then in evaluating, the teacher has also adjusted the assessment in accordance with the curriculum 2013.

In general, French is still seen as a difficult lesson by most of the students, so the achievement of students' French learning outcomes is still unsatisfying. There are two conflicting opinions in the middle of teaching French. On the one hand, many complaints were raised by students towards mastering French. Complaints are caused because students are considered unable to use French both verbally and in writing. On the other hand, some students say that the learning done only focuses on some material presentation such as grammar lessons, sentence structure, or just memorizing dialogues so 
that students indirectly assume that French language learning is very difficult.

One approach that can be used in French language learning is to use an optional approach, perspective actionnelle. This learning approach leads to the achievement of goals that prioritize the acquisition of language skills by making students as language's users (les acteurs). Through this approach, the teacher teaches using French during the process of delivering the material, so that the students can get used to listening to conversations in daily communication. If they do not know the meaning of a particular vocabulary, then the teacher can explain using the expression, movement, or by showing certain objects without having to interpret them into Indonesian. With this approach it is expected that students can better understand the true meaning of French, so that they can apply it in real life.

In the perspective actionnel, there are several methods that can be used, for example by using simulation methods. This method is a way of presenting the lesson by using imitation situations in the teaching and learning process to obtain an understanding of the nature of a particular concept, principle or skill. In the simulation method, students are involved directly in real situations. For example, students play role playing activities. By playing this role students will gain a clearer understanding of the person they are acting in, so that students can express their role in their tone of voice, voice, and facial expression. This material was motivated by the fact that speaking as a language skill was needed for various needs.

In connection with the approach in the learning process focusing on the task given to French learners, Ducrot (2006: 5) explains that:

La notion de " tâche" dans le CECRL, c'est la tâche est à relier à la théorie de l'approche actionnelle du cadre au sens de réalisation de quelque chose, d'accomplissement en termes d'actions. Autrement dit, l'usage de la langue n'est pas dissocié des actions accomplies par celui qui est à la fois locuteur et acteur social. (...)

The concept of "assignment" in the CECRL is a task that has a relation with the theory of the optional approach in accordance with the European General Terms of Reference (CECR) which aims to produce something, complete the terms of activity. In other words, the use of language is not separate from the language activities of a native speaker and social actor.

Learning using the optional approach has several components, namely culture, linguistics, pragmatics and sociolinguistics. Through these components, there are also social users who carry out shared tasks, and social environments (classes) where these language users perform their tasks. In 2010, Pecheur [2] showed an optional approach with the following scheme.

Therefore, teachers are expected to always plan scenarios and determine the scenes and sequences of events in the task. Furthermore, the learners work on these tasks by playing the characters in the scenes above. So, learning with this approach requires learners to always engage in activities and interact among fellow students in the classroom. The role of the teacher in the classroom is as a motivator and facilitator so that students are brave in expressing their opinions and feelings honestly. Learning in this way will make learners feel happy, active, not bored, and no longer feel afraid when doing wrong.

In this case, these tasks encourage students to make a dialogue and exchange opinions, with the aim that students can be encouraged to participate optimally, but still must follow ethics agreed upon. This activity will certainly involve all students and also motivate students to be able to communicate verbally and also writing. The results can also be observed and measured based on the assessment of the European General Terms of Reference (CECR).

\section{REVIEW OF THE LITERATURE}

\section{A. Description of Learning Approaches}

Learning using the perspective actionnel has several components, namely culture, linguistics, pragmatics and sociolinguistics. Through these components, there are also social users who carry out shared tasks, and social environments (classes) where these language users perform their tasks. In 2010, Pecheur [2] showed an optional approach with the following scheme.

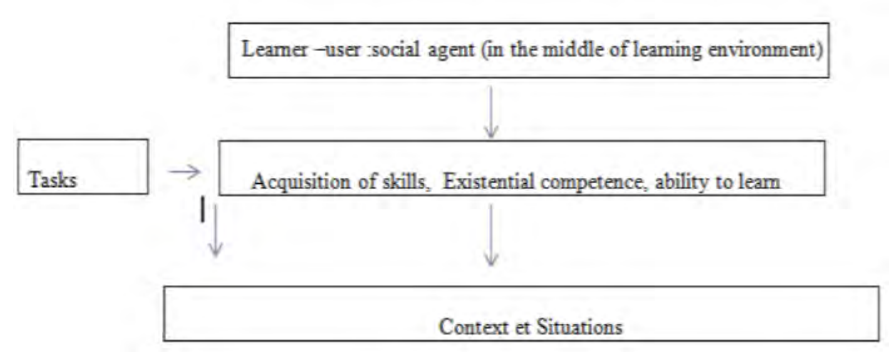

Fig 1. Learning Approaches

The communicative approach is an approach based on the idea that the ability to use language in communication is a goal that must be achieved in language learning. According to the CECR [1], l'approche Communicative est un terme de la didactique des langues correspondant à une vision de l'apprentissage basée sur le sens et le contexte de l'énoncé dans une situation de communication. The communicative approach is a term in language learning that matches the vision of learning based on meaning and the context of speech in a communication situation. The communicative approach directs the teaching of language to the purpose of teaching which emphasizes the function of language as a communication tool. The communicative approach of students is taught to obtain information needed in everyday life. In other words, the communicative approach can be interpreted as an approach that leads to the learning of communication whose purpose is that the purpose of language can be achieved in learning French.

\section{B. Description of Vocabulary Mastery}

Adisumarto [7] states about vocabulary, namely the lexicon of a language is a vocabulary that contains information about the meaning and use of words in a language. Vocabulary is closely related to the meaning of word lists compiled in a dictionary, but with a brief and practical explanation. 
According to Zuchdi [7] vocabulary mastery is a person's ability to know, understand, and use words properly and correctly, by listening, speaking, reading, and writing. Knowing the word is to get new words from the results of listening or from reading results. Furthermore, the essence of understanding words is obtaining new vocabulary, understanding words and their meanings and understanding the interrelationship of words and concepts beginning with these words. [6] states that vocabulary mastery is the ability to use words. The ability to understand is manifested in reading and listening activities, while the ability to use is manifested in writing and speaking activities. Based on the opinions above, then it can be concluded that vocabulary mastery is the ability to use precisely the words they have, both orally and in writing.

\section{METHOD}

This research was conducted in SMA Negeri 3 Medan at Budi Kemasyarakatan No. 3 in class 11th grade in the academic year 2018 / 2019. The population in this study is all students of class 11 th grade SMA Negeri 3 Medan consisted of 15 sciences classes and 4 social classes year 2018/2019 classes of classes 11 th grade. The sampling technique in this research is by cluster random sampling technique, social class 11 th grade 1 amounted to 45 students of the class given the learning with perspective actionnelle and social class 11th grade 3 amounted to 44 students of the class given the learning with communicative approach at SMA Negeri 3 Medan. The method used in this research is the experimental method (quasi experiment). The research design used is the factorial design 2 $\mathrm{x} 2$, which compares the perspective actionnelle and the communicative approach to higher vocabulary mastery and the lower ones.

TABLE 1 Design of Student Learning

\begin{tabular}{|c|c|c|}
\hline Class & Treatment & Postes \\
\hline Eksperiment & $\mathrm{X}$ & $\mathrm{T}_{1}$ \\
\hline Control & $\mathrm{Y}$ & $\mathrm{T}_{1}$ \\
\hline
\end{tabular}

Information:

$\mathrm{X}=$ Treatment in the experimental class is the application of perspective actionnelle

$\mathrm{Y}=$ Treatment in the control class is the application of the communicative approach.

$\mathrm{T} 1=$ Postes in the experimental class and control after treatment

To observe vocabulary mastery that is after students are grouped based on the test. The research design used is factorial design $2 \times 2$, which compares perspective actionnelle and communicative approach to higher and lower vocabulary mastery. The instrument in this study was to use 20 multiple choice test questions to measure learning outcomes, questionnaires to detect the vocabulary mastery. Hypothesis testing using two-way variance analysis technique $(2 \times 2$ factorial design) with a significant level of $5 \%$.

\section{RESULTS}

From the results of data analysis, researcher obtained the following data, such as : Normality test is done to determine whether the data is normally distributed or not. This study used chi-square table. Based on the calculation result, researcher obtained $\chi 2$ count for perspective actionnelle is 0.00285 while for communicative approach is 0.0432 . For $\chi 2$ table is 0.886 . Based on that result, researcher conclude that $\chi$ 2 count $<\chi 2$ table and data is normally distributed. Homogeneity test was conducted to obtain the assumption that the study sample were from the same condition. Homogeneity test was also conducted to find out whether both data had the same sample variance. Based on the calculation result, researcher obtained Fcount is 1,42 while Ftable is 1,82. Based on that result, researcher conclude that Fcount $<$ Ftable and data is homogeneous. The hypothesis formulated in this study is the students learning outcomes by using perspective actionnelle and communicative approach.

To know whether the students' learning outcomes by using perspective actionnelle is better than the students the communicative approach, researcher conducted calculation by using $\mathrm{T}$ test and the criteria are : Fcount $<$ Ftable, then H0 accepted and $\mathrm{H} 1$ rejected. Fcount $>$ Ftable, then $\mathrm{H} 0$ rejected and $\mathrm{H} 1$ accepted. Based on the calculation that used T test, researcher obtained Fcount is 4,34 while Ftable is 3,99. Researcher conclude the students who are taught by using perspective actionnelle is better than the students who are taught by using communicative approach.

Thus, the proposed research hypothesis that there is interaction between learning approach and vocabulary mastery to French learning results. When viewed from the average in groups of students who have high mastery vocabulary and are taught with a perspective actionnelle is higher than the average learning outcomes of other student groups. This is because learners can follow the learning well, where learners are able to express their opinion, discuss in a teamwork, and learning by playing the role. Meanwhile, in teaching and learning activities, either in a persepective actionnelle or communicative approach can take place interactively because the atmosphere of learning is fun. Learning using the perspective actionnelle of teachers is no learning center but centered on the students themselves. That is intended to provide an understanding to learners in knowing, understanding the various materials using this approach, that information can come from anywhere, anytime, regardless of teacher's inline information. The essence of this approach expects students to observe, question, reason, try, communicate (create networks) of everything related to the learning process itself. Through this approach students are expected to speak, write and can learn and work in groups.

\section{CONCLUSION}

The results showed that the outcomes of the students who are taught by perspective actionnelle are higher than the students who are taught by the communicative approach. There is an interaction between learning approaches and mastery vocabulary for the students' outcomes. There is a difference in the ability with higher vocabulary mastery, and, there is no significant difference on the students' who had the low vocabulary mastery. 


\section{References}

[1] Bailly, Nadine, Michael Cohen. L'approche communicative, Définition Générale Construtivisme vs Structuralisme Niveau Seuil. Accessed in April 2018 : http://flenet.rediris.es/tourdetoile/NBailly_MCohen.html

[2] Delibas, Murat, Rifat Gunday, "Action-Oriented Approach In Foreign Language Teaching." Turkey : Participatory Educational Research (PER), 2016, pp. 144-153.

[3] Devoucoux, Antoine Du Buysson, "Vous avez le projet d'obtenir un diplôme à l'étranger. Pourquoi pas la France ?" Accessed in April 2018 http://www.indonesie.campusfrance.org/fr

[4] Ducrot-Sylla, Jean-Michel, "Savoir mieux déterminer un profil de compétences adéquat chez l'apprenant selon les niveaux du CECRL." Suisse : DELF DALF. 2006. p.1.

[5] Jacques Leclerc,"Francophonie, qu'est-ce que la ?" Accessed in April 2018 Tlfq.ulaval.ca

[6] Nurgiyantoro, B. "Assessment of Language Learning." BPFE Yogyakarta. 2010

[7] Ubaidah, Erika. "The Effectiveness of the Use of Quiz Game Method in Class VII Vocabulary Learning at Junior High School". 2006 